Canadian University Music Review

Revue de musique des universités canadiennes

\title{
Barry Truax. Sequence of Earlier Heaven. Cambridge Street Records CSR 8501
}

\section{David Lidov}

Numéro 6, 1985

URI : https://id.erudit.org/iderudit/1014079ar

DOI : https://doi.org/10.7202/1014079ar

Aller au sommaire du numéro

\section{Éditeur(s)}

Canadian University Music Society / Société de musique des universités canadiennes

\section{ISSN}

0710-0353 (imprimé)

2291-2436 (numérique)

Découvrir la revue

\section{Citer ce compte rendu}

Lidov, D. (1985). Compte rendu de [Barry Truax. Sequence of Earlier Heaven. Cambridge Street Records CSR 8501]. Canadian University Music Review / Revue de musique des universités canadiennes, (6), 348-349.

https://doi.org/10.7202/1014079ar

(c) Canadian University Music Society / Société de musique des universités canadiennes, 1985
Ce document est protégé par la loi sur le droit d'auteur. L'utilisation des services d'Érudit (y compris la reproduction) est assujettie à sa politique d'utilisation que vous pouvez consulter en ligne.

https://apropos.erudit.org/fr/usagers/politique-dutilisation/ 
Barry Truax. Sequence of Earlier Heaven. Cambridge Street Records CSR 8501 (Available from: Cambridge Street Records, 4346 Cambridge Street, Burnaby, British Columbia, V5C 1H4, or Canadian Music Centre, Distribution Service, 20 St. Joseph Street, Toronto, Ontario, M4Y 1J9.)

This is the third record of the music of Professor Barry Truax of Simon Fraser University. It presents a set of four computer-assisted compositions realized 1981-1985. The first two employ tape recorded sound with a solo instrument, amplified tenor recorder in East Wind (1981) and marimba in Nightwatch (1982). The third and fourth are compositions of synthesized sound, Wave Edge (1983) and Solar Ellipse (1984-85).

The unities of each piece and of both pairs are impressive. In the works for instrument and tape, the recorded sounds are manipulations of the solo timbre. The transformed sounds bridge the recorder and marimba so that a broad palette of wood resonances links the two works. What I take to be a sharp staccato tongued directly on the recorder's emboucher becomes a diversity of "plucked" sound. For its part, the marimba readily supplies the material of sustained pedals which correlate with the drones of mechanically lowered recorder tones.

The synthesized pieces belong to a genre which Truax calls "soundscapes." Each sustains an obbligato pattern of spatial (that is, stereophonic) motion. These "spatial trajectories" are complex effects which seem to depend on formant and dynamic modulation for depth in addition to their graduated left/right balance. Perception of these, as with any musical hearing, improves with repetition. My own stereo imaging is always sluggish to start and I was glad to have the clues in Truax's notes. In Wave Edge, wave-like bands of noise move forward and break right to left. In Solar Ellipse four pitches and four noise bands swirl in epicycles, that is in quick small circles whose centers describe an orbit (this is, in other words, the motion of a planetary moon but without the planet). Even with just two speakers or with headphones the patterning becomes vivid.

Sequence of Earlier Heaven draws titles and imagery from the $I$ Ching. While I know rather little of this source or its culture, these do not seem to be casual or superficial borrowings. The whole sonic and structural character of the works displays a particular balance between expansion and delicacy, broad symmetry and quick nuance, which I am inclined to attribute to a reflective Orientalism. The imagery is more naturalistic than humanistic. In East Wind (I Ching Hexagram 9 "Taming Power of the Small ... . wind, heaven, clouds") quickly thickening harmonious drones support delicate modal solo figures. The droned chord rises and clarifies to unveil a sustained staccato passage. The drones return at even greater depths than before with a play of breath noise and a more dominating solo line that rises to a long leisurely trill at its climax.

In Nightwatch (Hexagram 16, "Enthusiasm . . . earth and thunder") 
sparse bits of dry pulse prepare a quiet entrance for the Marimba in the low register that hints at Phyrygian. Rapid treble ostinati combine with their own accelerated recorded images in an extended shimmer. Sprinkles of notes suggesting diminutions of the opening figures lead to a striking coda where subdued explosions are gradually penetrated by a hymn-like melody that the marimba and tape play in near unisons, layering long rolled notes upon themselves like facing mirrors. This piece seems a bit stiffer than East Wind; the marimba's part-writing is less fluid than the recorder's and relies overly on glissandi.

The synthesized compositions are still bolder and clearer in design than these first pieces. In Wave Edge ("Youthful Folly, ... water and mountain") the waves enfold us in a submarine vista of shiny, darting sounds. Plunging octaves pile up into deep rich chords which recall and enlarge the foghorn motif that frames the music. It is a work of sustained tonal beauty though the transition that brings us back to shore with slow out-of-phase beats sounds a bit pedantic. Solar Ellipse ("Revolution, ... fire and lake") is a staunch composition, its architecture a planetarium of strict cycles converging and diverging with a colossal climax right at midpoint. This piece, like the others but more thoroughly and dogmatically, reveals a tendency towards automation in its composition which purges the sound shape of nearly every impress of the individual, idiosyncratic human physique. It roots out the very basis of our subjective identification with music. The sonic object is alienating: dazzling in its presentation but dissappointing to memory, a technological display. But it is a towering display, a brilliant and fascinating spectacle. Toward its center the whole cosmos seems to slide and shake, almost to dance. Whether this was a moiré effect of the compounding patterns or an added intervention, I was not quite sure. The composer's metaphor depicts the music aptly: "fire whose energy is ... being dissipated yet, like the sun, appears to remain constant."

David Lidov

"SPells": Jack Behrens: Fiona's Flute. Dialogue. Peter RaCine Fricker: Two Spells for Solo Flute. Ballade for Flute and Piano, Op. 68. Bagatelles for Clarinet and Piano, Op. 83. Jack Behrens, piano; Robert Riseling, clarinet; Tsuyoshi Tsutsumi, violoncello; Fiona Wilkinson, flute. ORION MASTER RECORDINGS ORS 83455 (Available from: P.O. Box 4087, Malibu, California 90265).

This attractive record of five recent works provides an enjoyable sample of the music of two "transplanted" composers: Jack Behrens, since 1981 the Dean of the Faculty of Music of the University of Western Ontario, was born in Lancaster, Pennsylvania, and taught at California State College at Bakersfield, Simon Fraser University and the University 